\title{
GYRFALCON NEST SITE FIDELITY, BREEDING DISPERSAL, AND NATAL DISPERSAL IN ALASKA USING NON-INVASIVE GENETIC SAMPLING
}

\author{
Travis L. Booms ${ }^{1,2}$, Sandra L. Talbot ${ }^{3}$, George K. Sage ${ }^{3}$, Brian J. McCaffery ${ }^{4}$, \\ KeVIn G. McCRACKen ${ }^{1}$, AND PhILIP F. SCHEMPF ${ }^{5}$ \\ ${ }^{1}$ University of Alaska Fairbanks, Biology and Wildlife Department and Institute of Arctic \\ Biology, 211 Irving I, Fairbanks, AK 99775, USA \\ ${ }^{2}$ Current address: Alaska Department of Fish and Game, Wildlife Diversity Program, 1300 \\ College Road, Fairbanks, AK 99701, USA. E-mail: travis.booms@alaska.gov \\ ${ }^{3}$ US Geological Survey, Alaska Science Center, 4210 University Drive, \\ Anchorage, AK 99508, USA
}

${ }^{4}$ US Fish and Wildlife Service, Yukon Delta National Wildlife Refuge, P.O. Box 346, Bethel, AK 99559, USA

${ }^{5}$ US Fish and Wildlife Service, Migratory Bird Management - Raptors, 3000 Vintage Boulevard. Suite 240, Juneau, AK 99801, USA

\begin{abstract}
EXTENDED ABSTRACT.-Dispersal is one of the most important life history traits determining a species' persistence and evolution (Wiens 2001). It directly influences important ecological processes and individual quality. Understanding dispersal is important to properly interpret survey data and to assess the viability of populations. However, published information on site fidelity, breeding dispersal, and natal dispersal of individual Gyrfalcons (Falco rusticolus) is nearly non-existent.
\end{abstract}

We used molted feathers naturally shed from adult Gyrfalcons as non-invasive genetic samples following methods similar to those in Sonsthagen et al. (2004), Waits and Paetkau (2005), and Rudnick et al. (2005, 2008). We collected samples in breeding territories to document nest site fidelity, breeding dispersal, and natal dispersal at three study areas located 100-350 km apart on the Yukon Delta National Wildlife Refuge (Figure 1, Askinuks, Volca- noes, and Kilbucks), Alaska, from 2003-2007. We defined breeding dispersal as movement among nest sites and natal dispersal as movement from a bird's natal nest site to its nest site of first breeding. The number of feathers collected per individual per site ranged from 0-34 feathers (Figure 2). Gyrfalcons were highly faithful to study areas and territories; we documented no breeding dispersals among study areas and only one dispersal event between territories. Gyrfalcons exhibited low nest site fidelity; only $22 \%$ of birds returned to the same nest site the following year. The remaining 78\% moved 50-3,400 $\mathrm{m}$ from the previous alternate nest site. Dispersal distance averaged $750 \pm 870 \mathrm{~m}(\mathrm{SD})$, and was similar between sexes (females $754 \pm 950 \mathrm{~m}(\mathrm{SD}), \mathrm{n}=19$; males $745 \pm 740 \mathrm{~m}(\mathrm{SD}), \mathrm{n}=10)$. Mean annual turnover at the Volcanoes study area was $20 \%$. We detected three natal dispersal events ranging from $0-254 \mathrm{~km}$ representing $2.5 \%$ recruitment of the 121 sampled nestlings. 


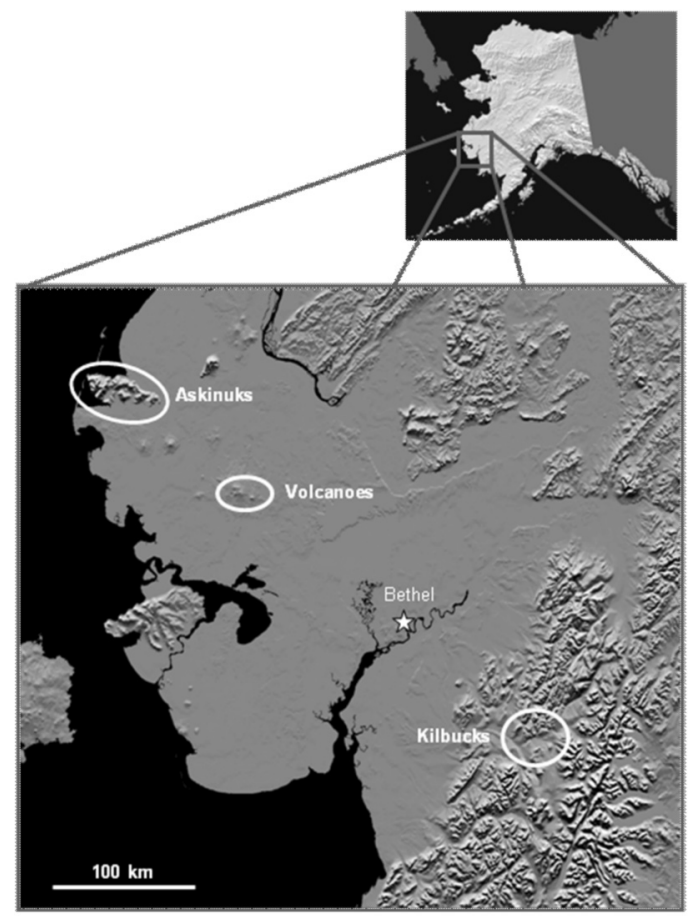

Figure 1. Study areas on the Yukon Delta National Wildlife Refuge from which Gyrfalcon genetic samples were collected, 2003-2007.
Here we provide some of the first documentation and description of Gyrfalcon nest site fidelity, breeding dispersal, and natal dispersal in North America. Gyrfalcons were highly site faithful but regularly used alternate nests. Understanding these movements greatly helps delineate territories, interpret survey data, and understand and predict the resiliency of the species to adapt to rapidly changing environments. Received 2 March 2011, accepted 9 May 2011.
Figure 2. Number of feathers in which unique individual male and female Gyrfalcons were detected per territory per year on Yukon Delta NWR from 2003-2007. Individuals detected in zero feathers in a given year were detected in consensus genotypes in previous and subsequent years, but were only detected in the given year by color band re-sightings or incomplete genotypes and were parental matches to nestlings.

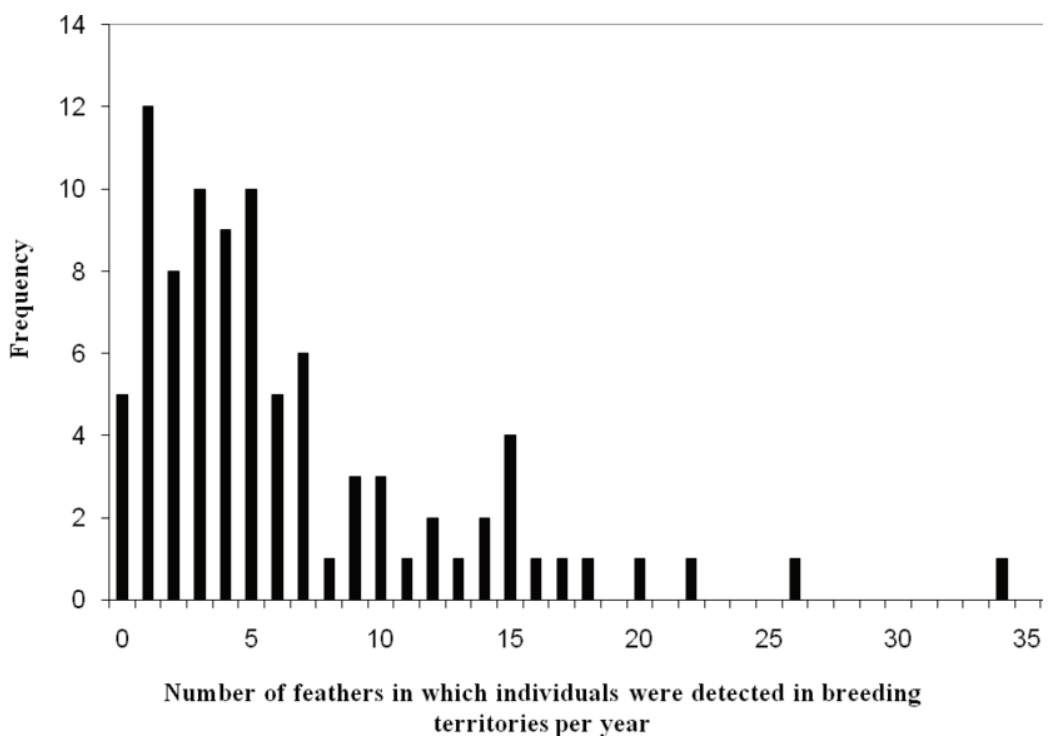


Booms, T. L., S. L. Talbot, G. K. Sage, B. J. McCaffery, K. G. McCracken, and P. F. Schempf. 2011. Gyrfalcon nest site fidelity, breeding dispersal, and natal dispersal in Alaska using non-invasive genetic sampling. Extended abstract, pages 291-294 in R. T. Watson, T. J. Cade, M. Fuller, G. Hunt, and E. Potapov (Eds.). Gyrfalcons and Ptarmigan in a Changing World, Volume I. The Peregrine Fund, Boise, Idaho, USA. http://dx.doi.org/10.4080/gpcw.2011.0203

Key words: Alaska, nest site, breeding dispersal, genetics, natal dispersal, Gyrfalcon.

This paper was originally published in full as: Booms, T. L., S. L. TAlbot, G. K. Sage, B. J. MCCAFFERY, K. G. MCCRACKEN, AND P. F. SCHEMPF. 2011. Nest-site fidelity and dispersal of Gyrfalcons estimated by noninvasive genetic sampling. Condor 113(4):768-778.

\section{ACKNOWLEDGMENTS}

This work was funded by the US Fish and Wildlife Service (USFWS) Yukon Delta National Wildlife Refuge, USFWS Office of Migratory Birds Raptor Management Office, US Geological Survey Alaska Science Center, USFWS's Surveillance Program for Highly Pathogenic Avian Influenza, Angus Gavin Migratory Bird Research Grant, and the David Burnett Dunn Memorial Research Grant. TLB was supported by a National Science Foundation Research Fellowship, a US Environmental Protection Agency (EPA) Science to Achieve Results Graduate Fellowship, a University of Alaska Thesis Completion Fellowship, and the Alaska Department of Fish and Game Wildlife Diversity Program while conducting various portions of this work. The EPA has not officially endorsed this publication and the views expressed herein may not reflect the views of the EPA. We thank the staff of the Yukon Delta NWR for providing essential support. M. Fuller, T. Swem, F. Broerman, and T. Doolittle provided essential collaboration. R. Blaedow, N. Dodge, B. Massey, J. Spice, M. Swaim, and B. Torrison provided invaluable assistance collecting field samples. J. Gust, C. R. Dial, and S. Sonsthagen provided curatorial, laboratory, and analytical assistance. Although PFS and BJM are employees of the US Fish and Wildlife Service, the findings and conclusions in this article are those of the authors and do not necessarily represent the views of the Service.

\section{Literature Cited}

Rudnick, J. A., T. E. Katzner, E. A. Bragin, O. E. Rhodes, ANd J. A. DeWoody. 2005. Using naturally shed feathers for individual identification, genetic parentage analyses, and population monitoring in an endangered Eastern Imperial Eagle (Aquila heliaca) population from Kazakhstan. Molecular Ecology 14:2959-2967.

Rudnick, J. A., T. E. Katzner, E. A. Bragin, AND J. A. DEWoOdy. 2008. A non-invasive genetic evaluation of population size, natal philopatry, and roosting behavior of nonbreeding Eastern Imperial Eagles (Aquila heliaca) in central Asia. Conservation Genetics 9:667-676.

Sonsthagen, S. A., S. L. Talbot, and C. M. White. 2004. Gene flow and genetic characterization of Northern Goshawks (Accipiter gentilis) breeding in Utah. Condor 106:826-836.

WAits, L. P., AND D. PAETKAU. 2005. Noninvasive genetic sampling tools for wildlife biologists: A review of application and recommendations for accurate data collection. Journal of Wildlife Management 69:1419-1433.

WiEns, J. A. 2001. The landscape context of dispersal. In J. Clobert, E. Danchin, A. Dhondt, and J. D. Nichols (Eds.). Dispersal. Oxford University Press, Oxford, UK. 
- BoOMS ET AL.- 